\title{
Plutarch i jego praktyczne znaczenie: bonae litterae Erazma z Rotterdamu
}

\section{Dawid NOWAKOWSKI*}

\begin{abstract}
Plutarch and the practical dimension of his oeuvre: bonae litterae of Erasmus of Rotterdam: The present essay aims to study the peculiarities of Plutarch's impact on the works of Erasmus of Rotterdam, and the importance of the Cheronean for the Erasmian concept of bonae litterae. The paper starts by tracing the origins and character of Erasmus' acquaintance with Plutarch's writings, then it emphasizes Erasmus' regard for the moral aspect of the Cheronean legacy and the privileged position of the Greek moralist within Erasmian thought.

KEYWORDS

Plutarch of Cheronea; Erasmus of Rotterdam; bonae litterae
\end{abstract}

* Mgr, doktorant w Instytucie Filozofii, Uniwersytet Łódzki. E-mail: d.nowakowski@ onet.eu. 
Z Plutarchem Erazm z Rotterdamu po raz pierwszy zetknął się bodaj w roku 1483, gdy jako czternastoletni zaledwie chłopiec słuchał w Szkole św. Lebwina w Deventer wykładów humanisty Aleksandra Hegiusa (1433-1498) ${ }^{1}$. Hegius, choć miał jedynie elementarną znajomość greki, swe wykłady z filozofii moralnej okraszał niekiedy przykładami z Plutarcha, a w poemacie De utilitate linguae graecae, zachęcat ponadto swych uczniów do samodzielnej lektury greckich autorów (Hyma, 1930: 82-83, 110n.; Woodward, 1906: 84-85)². Że Erazm z zachęty skorzystał jest faktem znanym i potwierdzonym przez pojawiające się w jego najwcześniejszych pismach liczne nawiązania do Plutarcha i innych helleńskich autorów. Jednakże dopiero podczas swego pierwszego pobytu w Anglii w latach 1499-1500, a więc mając już ponad trzydzieści lat, poczynił Erazm na tyle duże postępy $\mathrm{w}$ grece, by móc swobodnie czytać oryginalne dzieła $^{3}$. Pierwszy owoc tych studiów - tłumaczenie Odysei - nie zachował się, ale powstałe niedługo później przekłady niektórych mów Libaniusza (1503, ed. princ. 1519) oraz Hekuby i Ifigenii w Aulos Eurypidesa (1506) pokazują cate bogactwo zebranych na polu greki plonów (Giese, 1934: 520-521). Wreszcie, po ponad dwuletnim pobycie w Italii, współtworzy Erazm słynną edycję Aldina Moraliów Plutarcha (1509).

Jednak na pierwsze Erazmowe tłumaczenia Moraliów trzeba będzie poczekać aż do roku 1514, gdy ukażą się drukiem u Frobena w Bazylei jako Opuscula Plutarcbi, od razu w liczbie ośmiu traktatów ${ }^{4}$. Listę ich tytułów wylicza Erazm w słynnym katalogu własnych dzieł — są to: Quomodo sit dignoscendus adulator ab amico, Quo pacto fieri possit vt vtilitatem capias ex inimico, De tuenda valetudine, Quod in principe requiratur eruditio, Quod cum principibus maxime versari debeat philosophus, Vtrum grauiores sint animi morbi an corporis, De cupiditate diuitiarum, Num recte dictum sit, $\lambda \dot{\alpha} \theta \varepsilon \beta \imath \omega ́ \sigma \alpha \varsigma^{5}$. Przekłady te oparł Erazm na wydaniu Aldina, choć narzekał jednocześnie na liczne błędy w tekście i gdy

${ }^{1}$ Wykaz stosowanych w artykule skrótów: A = P. S. Allen (ed.), Opvs epistolarvm Des. Erasmi Roterodami, t. 1-12, In Typographeo Clarendoniano, Oxonii 1906-1958; ASD = Opera Omnia Desiderii Erasmi Roterodami, t. I-1-, l'Union Académique Internationale et de l'Académie Royale Néederlandaise des Sciences et des Sciences Humaines, Amsterdam 1969-; LB = J. Le Clerc (ed.), Desiderii Erasmi Roterodami Opera omnia, t. I-X, Lvgdvni Batavorvm 1703-1706. [Niekonsekwencje w ortografii tekstów łacińskich wynikają z przyjętej przez kolejnych wydawców metody transkrypcji - przyp. red.].

${ }^{2}$ Ledeboer, 1867: 127 odnotowuje obecność w bibliotece w Deventer łacińskiego tłumaczenia Żywotów Plutarcha (ed. Campani) z ok. 1473 roku.

${ }^{3}$ Pierwsza wzmianka o Plutarchu w korespondencji Erazma pojawia się w liście z 17 listopada 1503 do Nicholasa Ruistre („Auxit insuper fiduciam, quod recorderer olim, vt refert Plutarchus" [Apophth. LB IV 172b]), A, t. 1, s. 391.

${ }^{4}$ Pierwsze wzmianki o nowym tłumaczeniu pojawiają się jesienią 1512 roku w liście do Piotra Gillisa (Rummel, 1985: 72-73).

${ }^{5}$ List do Johannesa von Botzheim z 30 stycznia 1523 (A, t. 1, s. 3). W liście 271 do Tomasza Morusa z lipca 1513 (A, t. 1, s. 528) zaznacza Erazm, że najbardziej ceni sobie traktat Jak odróżnić pocblebcę od przyjaciela. Warto zwrócić tutaj uwagę, że Erazm powątpiewat 
tylko było to możliwe, starał się je od razu poprawiać (Rummel, 1989: XXXI) . Dla Erazmowych tłumaczeń charakterystyczne jest również to, że wyżej stawia on ich retoryczne oddziaływanie niż dosłowne znaczenie i często odchodzi od wiernego przekładu w stronę mniej lub bardziej dokładnej parafrazy. Związane jest to, o czym niebawem powiem nieco szerzej, z umoralniającą funkcją, na której podtrzymaniu Erazmowi w jego tłumaczeniach zależy najbardziej. Również $\mathrm{w}$ trosce o te moralne walory stosuje humanista niekiedy delikatną cenzurę, jak chociażby wówczas, gdy w Jak odróżnić pocblebcę od przyjaciela homoseksualne skłonności króla, opisywane greckim przymiotnikiem $\pi \alpha \iota \delta o \mu \alpha v \eta ́ s$ (szalejący za chłopcami), oddaje w ogólnych terminach przez „raczej wstydliwy rodzaj pożądania” (foediori libidinis generi) (Rummel, 1986: 76-79).

Po raz drugi do tłumaczenia Moraliów Plutarcha przystępuje Erazm po ponad dziesięcioletniej przerwie, by w 1525 roku wydać u Johanna Frobena grecko-łacińskie wydanie dwóch krótkich traktatów De non irascendo i De curiositate. Rok później, w lutym 1526 roku, jako apendyks do będącego swobodną wariacją na temat De garulitate dużego dzieła Erazma o języku - Lingua, ukazuje się ostatnie z Erazmowych tłumaczeń Plutarcha - De vitiosa verecundia ${ }^{7}$. (Napisanych bowiem przez Erazma w 1531 roku Apoftegmatów, z uwagi na ich luźne powiązanie z dziełem Plutarcha o takim samym tytule, nie sposób sensu stricto zaliczyć do pracy przekładowej; Domański, 1973: 63-66; Hajdukiewicz, 1961: 161-162; Ortiz, 2000: 81-82). Erika Rummel, która zestawiła i porównała wszystkie Erazmowe tłumaczenia Plutarcha, wskazuje na uderzającą statyczność poziomu jego językowych umiejętności. „Wydaje się - pisze - że wszystkiego, co potrzebne, nauczył się on już w pierwszych latach swych studiów; późniejsza trafność tłumaczeń odzwierciedla bardziej stan jego umysłu, niż kompetencje"8 (Rummel, 1985: 80).

Z dzieł Erazma, na których najsilniej zaciążyła twórczość Plutarcha, poza wspomnianym już wcześniej traktatem Lingua, wymienić należy przede wszystkim dwa: powstałe w 1514 roku, w dużej mierze jako „odprysk” przy tłumaczeniach Plutarcha, Parabolae sive similia oraz tworzony w następujących po sobie na przestrzeni ponad trzydziestu lat szeregach wydań, ogromny i przytłaczający swą erudycją zbiór przysłów Adagia (1500-1536).

Parabolae, jak pisze sam Erazm w dołączonym do dzieła liście dedykacyjnym do Piotra Gillisa, są zbiorem pewnego rodzaju porównań będących nie czym innym, jak poszerzonymi metaforami ${ }^{9}$. Zostały one zebrane przy okazji pracy nad kolejnym wydaniem Adagiów i złożone w cztery wydzielone przez autora

w autentyczność Num recte dictum sit, $\lambda \dot{\alpha} \theta \varepsilon \beta \iota \omega ́ \sigma \alpha \varsigma$, o czym pisze omawiając adagium Late vivens (Adag. II, X 50, LB II 696a).

${ }^{6}$ Zauważenie tych błędów mogło być skutkiem pogłębienia znajomości greki.

${ }^{7}$ Wydanie tłumaczeń Erazma znajduje się w LB IV 1-84.

${ }^{8}$ Gdy nie podaję inaczej, wszystkie tłumaczenia są mojego autorstwa.

${ }^{9}$ Ep. 312 do Piotra Gillesa z 15 października 1514, A, t. 2, s. 33. 
grupy: parabole pochodzące od Plutarcha, parabole pochodzące od Seneki, parabole pochodzące od Lukiana, Ksenofonta oraz Demostenesa i parabole pochodzące od Arystotelesa, Pliniusza i Teofrasta. Pierwsza z wymienionych grup zajmuje niemal połowę dzieła $\mathrm{i}$ - jak słusznie zauważa Peter Mack — stanowi ona „istotny środek transmisji idei Plutarcha do łacińskiego renesansu” (Mack, 2011: 88) ${ }^{10}$. Trzeba bowiem pamiętać, że wciąż nie wszystkie traktaty Moraliów były dostępne w języku łacińskim i na pełne ich tłumaczenie trzeba będzie poczekać aż do roku 1570 (wydanie Wilhelma Xylandra).

W Adagiach, składających się w swej ostatecznej wersji aż z 4151 przysłów, Plutarch cytowany jest — jeśli wierzyć sporządzonym indeksom — 618 razy i pod względem liczby cytowań ustępuje tylko Cyceronowi (892 razy) i Homerowi (666 razy) (Cytowska, 1973: XXI). Ponadto, jak stwierdza sam Erazm we wprowadzeniu do dzieła ${ }^{11}$, inspiracją były tutaj tworzone już w starożytności podobne zbiory przysłów (na przykład Arystotelesa i Chryzypa), z których to zbiorów jedynie jeden, właśnie Plutarcha, dotrwał do czasów renesansu, stanowiąc tym samym dla Erazma bezpośredni punkt odniesienia. Zresztą, również bezpośrednio z Plutarchowego zbioru zaczerpnął humanista przynajmniej kilkadziesiąt komentowanych adagiów ${ }^{12}$.

Z tych wyliczeń cytowań Plutarcha i dokonanych przez Erazma tłumaczeń jego pism jasno przezierają ogrom znaczenia i potęga wpływu, jakie myśl Beoty wywarła na renesansowego humanistę. Sam Erazm zresztą bynajmniej się od tej oceny nie odżegnuje i w wielu miejscach deklaruje swój podziw i uznanie dla autora Moraliów: „z greckich pisarzy żaden nie jest bardziej czcigodny i wart czytania”"13, jest Plutarch prawdziwym ,autorytetem ponad pospolitym tłumem”'4. Jako taki, jak pisze Erazm w liście z 1516 roku do Guillaume’a Budego, należy Cheronejczyk do najważniejszych autorów ${ }^{15}$.

Co jednak zdecydowało o tym uznaniu i co sprawiło, że mimo upływu czasu i mimo tak burzliwych przemian, jakie nawiedzity Europę na przestrzeni życia

${ }^{10} \mathrm{Z}$ łącznej sumy (obliczenia, na które się tutaj powołuję, są mojego autorstwa) 700 porównań pochodzących z Moraliów Plutarcha, 162 (ok. 23\%) pochodzi z dzieł przełożonych już przez Erazma (zastanawia tylko brak obecności De cupiditate diuitiarum). Ogólnie Erazm korzysta tutaj z 43 traktatów Moraliów. Nieustalone jest dokładne źródło jedynie trzech paraboli $\mathrm{z}$ tej grupy.

${ }_{11}$ Adag., prolegomena, LB II 4f. Chodzi tu, rzecz jasna, o Plutarchowe Apophtegmata.

${ }_{12}$ Zwłaszcza kilka serii adagiów: III, VII, 83-86, 88-98 (LB II 904c-905b, 906b-908a); III, X, 76-84 (LB II 944e-946e); IV, I, 6-10 (LB II 971c-973b). Nie wszystkie przysłowia z tego Plutarchowego zbioru są autentyczne.

13 „Nullus enim extitit inter Graecos scriptores Plutarcho, praesertim quod ad mores attinet, sanctior aut lectu dignior" (Ep. 2431 do Williama diuka Cleves, z 24 lutego 1531, A, t. 9, s. 128).

${ }^{14}$ Adag. I, VIII, 100 (LB II 333e).

${ }^{15}$ Ep. 421 do Guillaume'a Bude z ok. 19 czerwca 1516, A, t. 2, s. 255. Por. też Domański, 1973: 76. 
Erazma, jego podziw dla mądrości Plutarcha pozostał w istocie niezachwiany? Bo przecież ani odłączenie się Lutra od Kościoła, ani rzezie, jakie miały miejsce w 1525 roku za sprawą rewolucji chłopskiej w Münster, ani wreszcie nękające Erazma u schyłku życia przeczucie, że wspaniały projekt respublica litteraria być może nigdy się nie urzeczywistni, nie tylko nie były zdolne powstrzymać go przed niestrudzoną pracą nad przekładem Moraliów, ale wręcz przeciwnie, wszystkie te nieszczęścia — jak przekonujemy się chociażby z bazującego na De garrulitate traktacie Lingua ${ }^{16}$ - stanowity raczej pobudkę do tym usilniejszego propagowania Plutarchowych idei. Już te okoliczności wskazują niejako, że nie o samą uczoność tu szło i wcale nie o przyrost jedynie filologicznej wiedzy.

Należał Plutarch, i owszem, do najbardziej świattych ludzi, z jakich myślą Erazm się zetknął, i żaden ze starożytnych nie mógł się z nim pod tym względem równać. W przedmowie do przekładu De utilitate capienda ex inimicis niderlandzki myśliciel pisze:

Nawet Grecja sama, ta płodna matka wielkich umystów, nigdy nie wydała autora, który przewyższałby go [tj. Plutarcha - D.N.] w uczoności i wdzięku. Wątpię, by ktoś zdołał kiedykolwiek, tak jak on, złączyć znamienity styl z najbardziej dokładną wiedzą o [ludzkich - D.N.] sprawach $^{17}$.

Do bogatego skarbca porównuje często twórczość Plutarcha, w którym nawet najdrobniejsze traktaty, pozornie bez znaczenia, niczym drobne klejnoty okazują się bezcenne ${ }^{18}$. Z tej skarbnicy czerpał Erazm historyczne i przyrodnicze przykłady dla swych moralnych pouczeń, wiedzę o zwyczajach i wierzeniach starożytnych ludów, a także potwierdzenie ciągłości tradycji klasycznej z tradycją chrześcijańską ${ }^{19}$.

Jednakże to sfera moralności była właściwym obszarem, na którym wartość Plutarchowych idei była dla Erazma szczególnie wyraźna. Poczynając od koncepcji wychowawczych greckiego filozofa, które, jakkolwiek w renesansie znane i czerpane były przede wszystkim z Pseudo-Plutarchowego De liberis educandis, to jednak, skoro zależność tego dzieła od autentycznych poglądów Beoty jest powszechnie znana, zdominowały, jak się zdaje, edukacyjną myśl odrodzenia niemal na równi $z$ Kwintylianem ${ }^{20}$, a na dojrzałych zaleceniach etycznych kończąc. Również Erazm, o czym świadczą liczne miejsca w jego pismach, nigdy w autentyczność De liberis educandis nie powątpiewał ${ }^{21}$ i gdy w 1529 roku przy-

\footnotetext{
${ }^{16}$ Por. Lingua LB IV 690e-691f, 712c-e.

${ }^{17}$ Ep. 284, z 4 stycznia 1514 do Tomasza Wolseya, A, t. 1, s. 548-549.

${ }^{18}$ Por. Ep. 268, z 1 stycznia 1513 do Johna Yonge, A, t. 1, s. 521; Ep. 297, z lipca 1514 do Tomasza Wolseya, A, t. 1, s. 594.

${ }^{19}$ Por. Adag. I VI 27, LB II 232a-b.

${ }^{20}$ Zależność idei De liberis educandis od koncepcji Plutarcha omawia Korus, 1978: 125-128. $\mathrm{Na}$ temat obecności Plutarcha w myśli odrodzenia, patrz przyp. 9 niniejszego artykułu.

${ }^{21}$ Por. np. Adag. I, I, 2 (LB II 15d); I, VIII, 1 (LB II 302a); I, X, 73 (LB II 387e).
} 
stąpił do ostatecznej redakcji swojego dzieła $O$ wychowaniu dzieci, idąc śladem dobrze już utrwalonej w renesansie tradycji, w znacznej mierze oparł je właśnie na poglądach wyrażonych u Pseudo-Plutarcha. Nie chodzi tu nawet o mniej lub bardziej dokładne przytoczenia wybranych fragmentów dzieła i jego przypowieści, ale przede wszystkim o ideowy trzon ludzkiego szczęścia, który zdaniem Erazma, tak samo jak Pseudo-Plutarcha, stanowią przede wszystkim natura, wykształcenie i ćwiczenie ${ }^{22}$. Dynamika występująca pomiędzy tymi trzema elementami uzasadnia naczelne twierdzenie praktycystycznej filozofii tak Plutarcha, jak i Erazma, że cnota moralna jest czymś, czego można się uczyć i w czym można czynić postępy ${ }^{23}$.

Kiedy chcemy zatem określić najbardziej istotne znaczenie filozofii Plutarcha dla projektu Erazma, nie wystarczy wskazać jedynie na literackie aspekty łączącej obu myślicieli relacji ani też omówić edycje, tłumaczenia, a nawet czysto historyczne użycie przez tego drugiego dzieł Beoty, lecz zwrócić trzeba uwagę na sygnalizowane już przeze mnie w tytule niniejszego artykułu praktyczne znaczenie twórczości greckiego myśliciela ${ }^{24}$; słowem, odpowiedzieć należy na pytania o to, 1) jaką praktyczną użyteczność odnajduje Erazm w pismach i postawie filozoficznej Plutarcha i 2) jaki użytek z owej praktyczności robi on we własnych pismach. Część pierwszą powyższego zagadnienia omówimy na wybranych przykładowych fragmentach tekstu, drugą zaś przedstawimy dzięki analizie jednej z podstawowych kategorii erazmiańskiej filozofii, jaką jest kategoria bonae litterae.

Jak wspomniałem już wcześniej, Erazm do Plutarcha jako do skarbnicy informacji na temat starożytnych obyczajów, historii i użycia słów odwoływał się wielokrotnie i niewątpliwie to za sprawą tego zwłaszcza myśliciela uformowat swój obraz antyku. Niemniej jednak teraz idzie nam nie o czysto faktograficzne użycie dzieł Plutarcha, ale o jego użycie praktycystyczne, które przybierało zresztą różne formy. Pierwszą z nich, najbardziej zbliżoną do użycia faktograficznego, jest przytoczenie przez Erazma jakiejś opowieści z Plutarcha i naniesienie na nią naukowych poprawek, po czym nadanie jej nowego, nieobecnego u greckiego filozofa, moralizującego odniesienia. Przykładem niech będzie tutaj przytoczona przez Erazma w Lingua słynna opowieść o gęsiach przelatujących nad górami Taurus, której dodana zostaje nowa moralna lekcja:

Gęsi cierpią na złą reputację z powodu trajkotania, a Wergiliusz mówi o nich, że „wniecają harmider”; lecz gdy tylko migrują z Cylicji i przelatują nad rejonem Taurus, który

22 Des. Eras. Rot. De pueris (LB I 497a: natura, ratio, usus). Ps.-Plutarch De liberis educandis

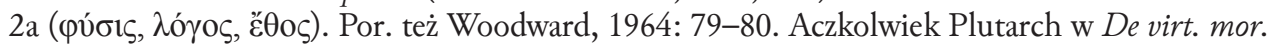

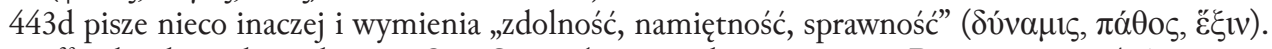

${ }^{23}$ Dla Plutarcha zwłaszcza Quis Suos 73b-86a. Dla Erazma np. De pueris LB I 491e.

${ }^{24}$ Por. Peters, 1967: 255. Tytuł tego artykułu stanowił źródło inspiracji dla tytułu mojego eseju. 
jest zapełniony przez orły, blokują swe tchawice haustem piasku i trzymają w swych dziobach kamień, i tak nocą przelatują w milczeniu. Kiedy są w połowie drogi nad górami wypuszczają kamień, a gdy są już wreszcie bezpieczne, zwracają piasek ze swych tchawic. Chociaż Plutarch przenosi tę historię (którą Pliniusz opowiada o żurawiach) na gęsi, przynajmniej również żurawie migrują zimą, podobnie jak bociany latem. Tak więc byłoby haniebne, jeśliby żurawie czy gęsi, które oba cierpią z pewnych powodów na złą reputację bycia głupimi (gęsi wśród Brytyjczyków, żurawie wśród Francuzów), miały więcej rozsądku od ludzi. Mężczyźni, którzy starają się o względy, zdobywają swe ukochane szybciej, jeśli wiedzą, jak zachowywać milczenie ${ }^{25}$.

W innym miejscu tego samego dzieła wykorzystuje Erazm czerpaną z pism Plutarcha wiedzę o antyczności dla skontrastowania jej obyczajów z moralnym upadkiem doby współczesnej. Mamy więc tutaj drugą z form praktycystycznego użycia, polegającą na wywoływaniu competitio, „współzawodnictwa” z żyjącymi w stanie sprzed łaski starożytnymi:

Plutarch wzmiankuje, że wśród Egipcjan zabronione było kapłanom picie wina. Lecz obecnie widzimy, że większość z nich jest pijana, gdy chrzczą dzieci, pijana, kiedy słuchają spowiedzi, i jest to najmniejszym z ich grzechów, jeśli zasną i nie zdołają usłyszeć, co zostało powiedziane, z tym zastrzeżeniem, że mimo tego czasami zdradzają to, co słyszeli ${ }^{26}$.

Trzecią z form praktycystycznego użycia pism Plutarcha, jaką udało mi się odnaleźć, tym razem w Erazmowych Adagiach, jest nadanie im funkcji „substytutu” doświadczenia, uczynienia z traktatu Plutarcha czegoś, co dzisiaj, mniej lub bardziej fortunnie, określilibyśmy chyba mianem „symulatora”:

Felix qui nibil debet. Szczęśliwy ten, kto nic nie jest dłużny. Popularny w grece aforyzm, prawda, która łatwo może być potwierdzona wielokrotnie przez każdego, kto wystawiony był na próbę bycia mocno zadłużonym. Ci bez takiego doświadczenia powinni przeczytać traktat Plutarcha $O$ tym, że nie powinniśmy pożyczać, gdzie szybko odkryją, jakim nieszczęściem jest bycie w długach ${ }^{27}$.

Czwarta forma praktycystycznego użycia dzieł Plutarcha pojawia się u Erazma chyba najczęściej i jest ze wszystkich form tego użycia formą najbardziej typową. Polega ona na takim wydobyciu obecnego w Moraliach parenetycznego wzorca, by ten stał się jeszcze bardziej godny podziwu i by jeszcze silniej skłaniał do naśladowania. Jednym z bardziej wyrazistych przykładów tego użycia jest występujące w Lingua wydobycie z ledwie zarysowanej w $O$ gadulstwie postaci Sokratesa, pełnej mężnego wigoru figury opanowującej namiętności:

${ }^{25}$ Des. Eras. Rot. Lingua, LB IV 685c-d. Plutarch o gęsiach przelatujących nad Taurusem pisze w De garr. 510a-b oraz w De soll. an. 967b-c.

${ }^{26}$ Des. Eras. Rot. Lingua, LB IV 686f-687a. Plutarch De Is. et Os. 353b.

${ }^{27}$ Adag. II, VII, 98 (LB II 637d). 
Wytrzymałość Sokratesa słusznie była przez wszystkich chwalona, ponieważ, sprzeciwiając się naturze, tak poprzez przymus i przyzwyczajenie opanował on i powstrzymał wszelkie swe namiętności, że zdawał się być ich zupełnie pozbawionym. Z wytrwałości ducha zdobył sobie równą wytrwałość ciała przeciwko każdym trudom, nieważne jak wielkim. [...] Po tym, jak wyćwiczył był swe ciało, na tę antyczną modłę, mając na względzie zdrowie, w porze, gdy napój jest najbardziej upragniony, nie zezwalał sobie na picie, póki pierwszy dzban nie został opróżniony przez innych — nie ze strachu przed upiciem się wraz z resztą, lecz by nauczyć swoje irracjonalne pragnienie czekać na rozkaz rozumu. W ten sam sposób zahartował swe ciało do niewiarygodnej wytrwałości w bezsenności, czuwaniu, cieple, zimnie i wysiłku. Człowiek, który tak owocnie utrzymuje swe pragnienia we władzy, będzie zdolny również do powstrzymywania świerzbiącego języka. [...] Taka ostrożność w mowie nie powinna być wywołana usposobieniem mówcy, lecz względem na słuchaczy. Zostanie to osiągnięte, kiedy nie będziesz zważał na to, co jest przyjemne dla ciebie, ale na to, co sprawia przyjemność i pożytek innym ${ }^{28}$.

Jak widzimy, Erazm bezpośrednio po opisaniu niezwykłości etopeicznego wzorca Sokratycznego, używając drugiej osoby liczby pojedynczej zwraca się wprost do czytelnika, w czym znakomicie naśladuje technikę Plutarcha. Tak naprawdę, przecież to dopiero grecki myśliciel ze swoim naciskiem na sprawy moralne i zwracaniem szczególnej uwagi na interpretację tropologiczną ${ }^{29}$ pojednał filozofię z prostym człowiekiem, rozwijając tym samym tak drogą Erazmowi ideę popularyzacji filozofii. W liście dedykacyjnym z 30 kwietnia 1525 roku do Alexiusa Thurzo, poprzedzającym tłumaczenie dwóch traktatów Plutarcha (De non irascendo i De curiositate), renesansowy humanista wprost wyraża przekonanie o tej praktyczności Moraliów:

Sokrates ściągnął filozofię z nieba na ziemię, Plutarch przywiódł ją w zacisze domu i do badania, i do naszych sypialni. [...] Zagadnienia, które Plutarch omawia w tych traktatach są tego rodzaju, że każdy w każdym czasie znajdzie ich natychmiastowe zastosowanie do zwyczajnych życiowych trosk ${ }^{30}$.

W tych krótkich słowach ujawnia Erazm, jakkolwiek nie wprost, również własne rozumienie filozofii i jej roli. Deklaratywnej zresztą definicji pbilosopbia nie odnajdziemy, na co wskazuje Juliusz Domański, w żadnym z pism Rotterodamczyka (Domański, 1973: 12, 96). Dlatego też, jak sądzę, dobrym posunięciem, dla rekonstrukcji tego pojęcia będzie tutaj odwołanie się do słów jednego ze współczesnych Erazma, Willibalda Pirckheimera (1470-1530), jakie daje on w przedmowie do swego przekładu De bis, qui tarde a numine corripiuntur Plutarcha (1513) - przekładu, notabene, bardzo przez Erazma chwalonego ${ }^{31}$ :

\footnotetext{
${ }^{28}$ Des. Eras. Rot. Lingua, LB IV 737f-738b. Por. Plutarch De garr. 513c-d.

${ }^{29}$ Por. Plutarch Quomodo adul. 19e.

${ }^{30}$ Ep. 1572 do Alexiusa Turzo z 30 kwietnia 1525, A, t. 6, s. 72.

${ }^{31}$ Pirckheimera chwali Erazm w liscie 362 z 16 października 1515, A, t. 2, s. 151.
} 
Prawdziwa filozofia naucza cnoty i daje pocieszenie w trudnym czasie. Rozważa ona te rzeczy, które bezpiecznie i pewnie prowadzą człowieka, błąkającego się i dryfującego po tym ziemskim morzu, do wrót najwyższego szczęścia i nieśmiertelności; a także te rzeczy, które goją rany odniesione w ludzkich niepowodzeniach i niedolach (cyt. za: Overfield, 1984: 155-156).

W tym samym zresztą duchu pisze, tym razem już o filozofii Erazma, jeden z jego korespondentów Augustinus Aggeus, uważając ją za „wiosło”, dzięki któremu można, unikając groźnych fal, kierować życiem, jak również odnajdywać w wyrażających ją traktatach iście terapeutyczną wartość i źródło pocieszenia ${ }^{32}$. Nieprzypadkowo takie praktyczne rozumienie filozofii pojawiło się u Erazma w kontekście prac i dyskusji nad pismami i dziełem Plutarcha, skoro — jak ostatnio przekonywująco udowodnił Lieve Van Hoof - właśnie na „stosowalności” opiera się myśl tego ostatniego, kierując swe wysiłki ku ułatwieniu swym odbiorcom właściwego życia w społeczeństwie (Hoof, 2010: passim). Skoro zarówno w filozofii Erazma, jak i w filozofii Plutarcha, moralnością czy też etyką, o której się mówi, jest etyka zrealizowana ${ }^{33}$, etyka, dla której wartością jest nie tyle sama wiedza, co raczej moralny czyn, istotnym zagadnieniem staje się moralny status owego „mówienia”, status samego etycznego przekazu, który możemy zrównać z zagadnieniem moralnego statusu pisma czy też litterae. To, że Erazm zdawał sobie sprawę $\mathrm{z}$ istnienia tej kwestii, nie budzi moich wątpliwości, gdyż w używanym przez niego, wartościującym moralnie, pojęciu bonae litterae widzę tej trudności przezwyciężenie. Tym jednak, na co chciałbym tutaj zwrócić uwagę i co postaram się udowodnić, jest wpływ myśli Plutarcha na wypracowanie ostatecznego kształtu tego pojęcia.

Zacznijmy od przypomnienia, że określenie bonae litterae, tak często łączone z imieniem Erazma, nie jest bynajmniej jego wytworem i że już przynajmniej od drugiej połowy XV wieku pojawiają się świadectwa jego użycia. Co prawda, wciąż bardziej popularne jest w quattrocento obecne już u Petrarki i bardziej wyraźnie związane ze sferą moralności określenie bonae artes, jednakże, jak się zdaje, to początkowe użycie obu z tych określeń nie zakładało między nimi wyraźnej różnicy i sprowadzało się w gruncie rzeczy do tego, co włączywszy później w obręb uniwersyteckiego curriculum, określono mianem studia bumanitatis ${ }^{34}$. Również Erazm w swych najwcześniejszych użyciach terminu bonae litterae

${ }^{32}$ Ep. 511 do Augustyna Aggeusa z 10 stycznia 1517 (?), A, t. 2, s. 428-429.

${ }_{33}$ Por. Plutarch An seni respublica gerenda 796c-f; Ep. 2533 do Seweryna Bonera z 1 września 1531, A, t. 9, s. 339. Na temat praktycyzmu Erazma, patrz: Domański, 1973: 57-76, 178; Pelc, 1984: 52.

${ }^{34}$ Określenie bonae artes (które pojawia się w starożytności u Aulusa Gelliusza — Noctes Atticae XIII, 17: „eruditionem institutionemque in bonas artes”) odnalazłem już w Familiaria rerum Petrarki (8.4.23: „Nos vero quid impedit quominus has vite reliquias, quantulecunque sunt, simul in pace animi bonarumque artium [podkr. D.N.] studiis transigamus..."). Później pojawia się ono (w liczbie pojedynczej jako bona ars) u Bruniego (Ad Petrum Paulum 
które datują się dopiero od roku 1497 (jako że nawet w Antibarbari został on dodany przez niderlandzkiego filozofa dopiero $\mathrm{w}$ drugim wydaniu $\mathrm{w}$ roku $1518)^{35}$, nie dostrzega żadnej różnicy pomiędzy tym pojęciem a pojęciem studia bumanitatis i używa ich zamiennie ${ }^{36}$. W taki też sposób pojęcie bonae litterae rozumiane jest w powszechnie znanej biografii Erazma autorstwa Johannesa Huizingi, który uznaje, że „pojęcie to obejmuje całą literaturę klasyczną, naukę i wykształcenie, uznane jako zdrowe i zbawienne $\mathrm{w}$ przeciwieństwie do średniowiecznego sposobu myślenia” (Huizinga, 1964: 145-146). Jednakże, na co wskazuje klasyczne już chyba studium Domańskiego, Erazmowe pojęcie bonae litterae bynajmniej nie jest jednoznaczne i przyjmuje różne zakresy w zależności od kontekstu, w jakim jest używane (Domański, 1973: 97n.). By zrozumieć przyczyny takiego stanu rzeczy, najlepiej skierować swą uwagę ku stojącej — jak mniemam - u źródła wieloznaczności pojęć Erazma myśli Plutarcha.

Z pism Plutarcha poruszających zbliżoną do tu dyskutowanej tematykę na szczególną uwagę zasługują dwa zwłaszcza traktaty: O stuchaniu i Jak młodzież powinna stuchać poetów; dodajmy, że również Erazm w swych wywodach będzie się właśnie na nie powoływał. Pisma te poświęcone są kwestii pożytku, rzecz jasna, moralnego, jaki odnosimy z czytania literaturyidzie tu,. Kwestia była nagląca o tyle, że będący dla Plutarcha ideałem filozofa Platon w słynnym

Histrum Dialogus, [w:] Garin, 1951: 54), wielokrotnie u Guarino Veronese (Epistola, [w:] Garin, 1951: 316, 318, 322, 326, 328, 372) i Albertiego (Intercoenales, [w:] Garin, 1951: 650, 654). Wreszcie w 1464 roku Bartolomeo Sacchi (znany szerzej jako Platina) wygłosił mowę De laudibus bonarum artium ad Pium II Pont. Max. Termin bonae litterae pojawia się już przynajmniej w 1460 u, znanego jako ucznia Guarina, Ludovica Carbone z Ferrary, jednakże w rozumieniu ogólnie literatury starożytnej (Oratio babita in funere ... Guarini Veronensis, [w:] Garin, 1951: 390: „Iacebat Priscianus, ignorabatur Servius, incognita erant opera Ciceronis, miraculi loco habebatur, si quis Crispum Sallustium, si quis C. Caesarem, si quis T. Livium nominaret, si quis ad veterum scriptorum intelligentiam aspiraret. Quadragesimus fere annus cives nostros in ludo puerili occupatos inveniebat in iisdem elementis semper laborantes, semper convolutos. Usque adeo bonarum litterarum ruin facta erat”. W tym samym duchu termin ten użyty jest na s. 402). Erazm mógł termin bonae litterae przejąć od Hermolao Barbaro (por. np., Epistolae, [w:] Garin, 1951: 840, 860 [przekład polski J. Ochman, [w:] Nowicki, 1966: 125-137]); szerzej na temat zależności Erazma od włoskiego renesansu pisze Kristeller, 1970: 1-14. Szerzej, choć nie zawsze precyzyjnie, pisze na temat tych pojęć Swieżawski, 1974: 106n. Por. także Kalita, 1992: 13 i przede wszystkim Domański, 2005: 241-249.

${ }^{35}$ Erazm potraktował $\mathrm{w}$ tym dziele pojęcie bonae litterae jako równoznaczne ze studia bumanitatis i zastąpił nim obecne we wczesnej wersji terminy litterae seculares i literatura gentilis. Por. K. Kumaniecki, (Antibarbari) Introduction, [w:] ASD I-1: 23. W słynnym wydaniu Lejdejskim (LB X 1693a-1744e) zamieszczono jedynie poprawioną w 1518 roku przez Erazma wersję Antibarbarorum i dopiero w 1930 roku Albert Hyma (Hyma, 1930), jako apendiks, wydał po raz pierwszy drukiem najwcześniejszą wersję tego dzieła z lat 1494-1495.

${ }^{36}$ Ep. 52 z 4 lutego 1497 do Jana Mauburna, A, t. 1, s. 167: „ad litterarum vero bonarum studiosos ita propensus sum vt vel aemulos amem”; Ep. 66, z 1497 (adresat nieznany), A, t. 1, s. 194: „idque maximum habere momentum, cum caeteris in rebus omnibus, tum precipue in bonarum studiis litterarum”. 
ustępie swojej Politei poetów z państwa wygania. Pogodzenie tych sprzecznych twierdzeń - mianowicie twierdzenia o pożytku z poezji z twierdzeniem o płynącej z niej szkodliwości — odnajduje Cheronejczyk w kryterium właściwego nastawienia. Jak czytamy w drugim z wymienionych traktatów Plutarcha:

W głowie polipa zarówno tak zło, jak i dobro się mieści - smaczny jest bowiem w jedzeniu, ale sprowadza zły sen, który, jak powiadają, przynosi budzące trwogę i dziwaczne widziadła. Podobnie poezja zawiera w sobie wiele wdzięku i przynosi pożytek duszy młodzieńca, lecz w nie mniejszym stopniu powoduje niepokój i wprowadza go na złą drogę, jeśli słuchanie poezji nie odbywa się pod właściwym kierownictwem ${ }^{37}$.

Zadaniem przeto filozofa jest swymi kształcącymi umiejętnościami owo odpowiednie nastawienie wzbudzić — i w tym kierunku właśnie idzie większa część wychowawczej działalności Plutarcha. Innymi słowy, przy takim rozumieniu „pożytecznej literatury” (bonae litterae) jej zakres zależny jest nie od jej immanentnych właściwości, ale raczej od umiejętności odpowiedniego jej spożytkowania. Erazm ochoczo przejmuje to rozumienie bonae litterae i wykorzystując pojawiającą się u Plutarcha metaforę pszczoły, włącza je w zestaw swoich Parabolae:

Jak pszczoła zbiera z kwiatów nektar na swój miód, podczas gdy inne stworzenia czerpią jedynie przyjemność z barwy i zapachu, tak też student filozofii nawet w poezji odnajduje rzeczy, które mogą przyczynić się do dobrego życia, podczas gdy inni znajdują jedynie przyjemność i odpoczynek ${ }^{38}$.

W takim ujęciu przez bonae litterae rozumieć będzie Erazm, zgodnie z przytoczoną wcześniej definicją Huizingi, całą literaturę starożytną i wszelkie w ogóle pisma, które przy odpowiednim nastawieniu odbiorcy mogą wydatnie przyczynić się do jego moralnego dobrostanu ${ }^{39}$. Zwraca jednocześnie uwagę fakt, że tak rozumiane bonae litterae są pojęciem szczególnie narażonym na nieobiektywną (bo subiektywną) określoność swego zakresu, a jego znaczenie

${ }^{37}$ Plutarch Quomodo adul. 15b-c. Por. Korus, 1978: 79.

${ }^{38}$ Des. Eras. Rot. Parab. LB I 582b. Por. Plutarch Quomodo adul. 30c-d. Warto wspomnieć, że ów słynny motyw pszczoły pojawia się już w Enchir. LB V 9d-e, aczkolwiek daleki byłbym od łączenia jego tam obecności ze znajomością Plutarcha, jako że występuje on również u dobrze znanego podówczas Erazmowi Valli (por. L. Valla, In quartum librum Elegantiarum praefatio, [w:] Garin, 1951, s. 622), u Horacego (Carm. 4.2.25-32) i u Seneki (Ep. 84).

${ }_{39}$ Por. np. Ep. 61 z sierpnia 1497 do Christiana Northoffa (bez użycia samego terminu bonae litterae), A, t. 1, s. 183; Ep. 335 do Leona X z 21 maja 1515, A, t. 2, s. 80; Ep. 1572 do Alexiusa Turzo z 30 kwietnia 1525, A, t. 6, s. 71; Ep. 1805 do Jana Maldonatusa z 30 marca 1527, A, t. 7, s. 14, 19; Ep. 2379 do Germanusa Brixiusa z 3 sierpnia 1530, A, t. 9, s. 40; Ep. 2423 do Augusina Trivulzio z 30 stycznia 1531, t. 9, s. 110; Enchir. LB V 66b-c; Ep. 337 do Marcina Dorpa z końca maja 1515, A, t. 2, s. 99, 108; Querela LB IV 628d; Rat. ver. theol. LB V 82b-c. 
nie zawsze pokrywać się będzie z nazbyt okrzepłym już w XVI wieku pojęciem studia bumanitatis.

Poza tym rozumieniem „pożytecznej literatury”, które zasadza się na odpowiednim nastawieniu u odbiorcy, istniała u Plutarcha również druga, bardziej właściwa jej definicja, odwołująca się już nie do czytelniczej postawy, ale do zamierzeń twórcy. Bowiem „pożyteczną literaturą” par excellence jest nie tamta, której „użyteczność” zależna jest od przypadkowej jedynie względem niej umiejętności słuchania, lecz ta, której już sama forma przemawia do odbiorcy w taki sposób, że nawet zupełnie nieuprzedzonego skłania ku moralnej poprawie. W taki też sposób konstruował swoje dialogi Plutarch, by wewnętrzna dynamika dialogu skłaniała czytelnika do spontanicznego podejmowania trudu zbadania samego siebie i do wynikającej stąd chęci poprawy (Hoof, 2010: 44; Brożek, 1977: XVIII). Obecność czynników wywołujących te dwa elementy, krisis - czyli przeświadczenie i askesis - czyli ćwiczenie (Hoof, 2010: 48-49), stanowi niezbędną zasadę konstytucyjną wzorcowej „pożytecznej literatury”. Tak skonstruowaną literaturę zażywa się niczym lekarstwo. Jak pisze Plutarch w De audiendo:

Jeśli nasze myślenie wzburzy jakaś złość albo siła zabobonu, gwałtowna sprzeczka z domownikami czy też namiętne pożądanie miłosne targające nietykalne dotąd struny duszy, nie powinniśmy, unikając rachunku sumienia, gonić za deklamacjami na inne tematy, ale słuchać konferencji poświęconych właśnie temu, a potem zastanowić się nad owymi sprawami, by podjąć pewne postanowienia ${ }^{40}$.

Erazm doskonale rozpoznał tę umoralniającą naturę Plutarchowego piśmiennictwa, o czym świadczy nie tylko wzmianka w katalogu jego pism stwierdzająca, że nic poza Pismem Świętym nie może równać się z siłą jego moralnego tonu $^{41}$, ale także często przywoływany cytat ze Zbożnej biesiady głoszaccy, że łatwiej przebolałby Erazm stratę Szkota z jemu podobnymi niż „księgi jednego Cycerona czy Plutarcha”, gdyż dzięki nim, jak czuje, „staje się lepszy”ł2. Również gdy sięgniemy do dzieł Erazma, już z samych tytułów większości z nich wywnioskujemy, iż nie inne niż praktyczna pomoc i rada cele towarzyszyły mu przy ich kompozycji. Dla przykładu weźmy choćby Przygotowanie do śmierci, Paraklezę to jest zachęte do uprawiania filozofii chrześcijańskiej czy w końcu słynny Podręcznik żotnierza Chrystusowego — wszystkie one, co łatwo wykazać, składają się z obu tych właśnie części: krisis i askesis. Wreszcie, gdy skierujemy się do ukończonego w przedostatnim roku życia Erazma, będącego istną summą jego filozofii, Ecclesiastesa (1535), w radach, jakie daje on tytułowemu kaznodziei, części te - krisis i askesis - pojawiają się ponownie:

\footnotetext{
${ }^{40}$ Plutarch De aud. 43d-e (przeł. M. Szarmach).

${ }^{41}$ A 1341a, A, t. 1, s. 3.

${ }^{42}$ Des. Eras. Rot. Conv. Rel. LB I 682a-b.
} 
Cała powinność duszpasterza w tym się mieści, iz wszystko na tym polega, by najpierw wyrwał on z dusz swych słuchaczy korzenie złych myśli i niegodziwe nasiona bezbożnej nauki, z których wyrastają przykre owoce, i zniszczył budowlę wzniesioną na złym fundamencie; wyplenił wyrosły kąkol i zrujnował źle postawiony gmach. W miejsce tego, co zostało wyrwane i zniszczone, posiewa on dobre ziarna i wznosi budynek, który nie będzie ustępował świątyni ${ }^{43}$.

Wspominając o tym podobieństwie natury Erazmowego piśmiennictwa z Plutarchowym, nie zawsze zresztą wprost etykietkowanego terminem bonae litterae, pragnąłem unaocznić nie tyle nawet bezpośrednią linię wpływu i oddziaływania - gdyż ta posiadała liczne odniesienia również od Seneki, Cycerona, Kwintyliana, ojców Kościoła i Lorenza Valli - ale raczej pewne podobieństwo nastrojów i celów, które okazało się, jak mniemam, naczelną iskrą pobudzającą ściśle praktycystyczne pojmowanie filozofii przez Erazma. Innymi słowy, nawet jeśli wymienieni przed chwilą myśliciele potrafili przekazać Erazmowi konceptualne ramy humanistycznego praktycyzmu i jego teoretyczne zaplecze, to jednak dopiero Plutarch wypełnił te ramy działającą i owocną treścią, której umoralniających właściwości Erazm, a wraz z nim i inni czytelnicy, mogli teraz na sobie doświadczać. W ten sposób, by tak rzec, słowo ciałem się stało, a oddziaływanie myśli moralnej Plutarcha wkroczyło na nowy poziom, transcendujący czysto historyczne czy też egzemplaryczne użycie, jakie omówiliśmy w poprzedniej części, i rozpoczęło bardziej żywotną, bo dynamiczną, egzystencję w sferze erazmiańskiego projektu wychowania już nie obywatela ziemskiej społeczności, ale wzorcowego członka społeczności niebiańskiej chrześcijanina. Najpełniejszym wyrazem i potwierdzeniem tego „wcielenia” ideałów Plutarcha i zespolenia w jedno z postawą chrześcijańską, jest nawiązujące do wcześniejszych nieco, a cytowanych przeze mnie w innym kontekście słów o dokonanym przez Plutarcha „przywiedzeniu filozofii do naszych sypialni”, określenie własnej swej roli przez Erazma słowami z De utilitate colloquiorum:

Sokrates sprowadził filozofię z nieba na ziemię; ja wprowadziłem ją nawet do zabaw, pogwarek i pijatyk. Godzi się bowiem, aby i rozrywki chrześcijan miały smak filozofii (przeł. J. Domański) ${ }^{44}$.

Poprzez to utożsamienie z postawą Plutarcha, jakie dokonało się pod szyldem bonae litterae Erazm odzyskał nie tylko zgodność swej myśli z patrystyczną tradycją, dla której - o czym świadczy chociażby słynna Mowa do młodzieńców Bazylego Wielkiego - literatura pogańska stanowiła wsparcie w moralnej trosce o duszę, ale także ugruntował tak ważny dla humanistycznego projektu ideał jedności sztuk i studiów. W pojęciu bowiem bonae litterae dzięki swej

${ }^{43}$ Des. Eras. Rot. Eccles. I ASD 8-5, s. 82-83.

${ }^{44}$ Des. Eras. Rot. De util. coll., LB I $904 d$. 
egzemplarycznej funkcji poezja jednała się z filozofią moralną, filozofia zaś w swym ekshortatywnym nastawieniu — z retoryką. Wreszcie - i na tym polegała decydująca siła koncepcji Plutarcha - tak pojęta etyka praktyczna stawała się prawdziwą propedeutyką pobożności, co pozwoliło później Erazmowi na uzyskanie jedności bonae litterae również $\mathrm{w}$ relacji wertykalnej z litteratura divina i uznanie, że tak jedna, jak i druga literatura zmierzają w gruncie rzeczy do jednego celu i tylko stopień doskonałości jego realizacji decyduje o różnicach między nimi ${ }^{45}$.

\section{ZASADY PRZYWOŁYWANIA TEKSTÓW ŹRÓDŁOWYCH}

Numeryczne odwołania do tekstów Plutarcha odwołują się do standardowej paginacji stosowanej w naukowych edycjach Moraliów (Olearius). Odniesienia do tekstów Erazma i innych humanistów zgodnie z ususem stosowanym w literaturze fachowej, spis skrótów oraz wydań dzieł myśliciela z Rotterdamu w przyp. 1.

\section{BIBLIOGRAFIA}

Brożek, M. (1977). Wstęp (s. III-LXIX). W: Plutarch z Cheronei. Żywoty sławnych mężów (z Żywotów równoległych). (Przeł. M. Brożek). Wrocław: Zakład Narodowy im. Ossolińskich.

${ }^{45}$ Erazm zwłaszcza w swych późniejszych listach, gdy coraz rzadziej już używa pojęcia bonae litterae, skłania się ku podkreślaniu jego bezpośredniego związku z naturą Ewangelii. Por. Ep. 1828, do Williama Warhama z ok. 26 maja 1527, A, t. 7, s. 75 („Excitaui plurimos ad bonarum litterarum studium, quin et theologorum studia tot lucubrationibus meis vel excitaui vel adiuui”); Ep. 1973 do Nicholasa Variusa z 19 marca 1528, A, t. 7, s. 360 („Euangelicos istos quum aliis multis, tum illo nomine praecipue odi, quod per eos vbique languent, frigent, iacent, intereunt bonae litterae; sine quibus quid est hominum vita? [...] Satis iamdiu audiuimus Euangelium, Euangelium, Euangelium; mores Euangelicos desideramus”); Ep. 1976 do Hermanna z Wied, z 19 marca 1528, A, t. 7, s. 362 („Nunc quum faucas ne de facie quidem noto neque quicquam vnquam promerito, sic interpretor, celsitudinem tuam non Erasmo fauere, sed quum optimis studiis tum Christianae pietati; quod illis restituendis ac prouehendis, huic tranquillandae stabiliendaeque, videar aliquam operam impendisse, quam felicem nescio, certe sedulam. Nam et bonae litterae propemodum expecatione felicius per omnes orbis regiones effloruerunt, et complures qui prius fuerant a sacris studiis alienissimi, correpti sunt horum amore”); Ep. 2054 do Erarda de la Marck, z 1 października 1528, A, t. 7, s. 503 („et nimium licet quibusdam stolidis monachis ac theologis, qui fidei Catholicae titulo belligerantur aduersus bonas literas et harum cultores, nonnulli etiam aduersus ipsum Euangelium”); Ep. 2644 do Conrada Gocleniusa z 3 maja 1532, A, t. 10, s. 17 („Hic quotquot callent bonas literas, amant Euangelium”); Ep. 3032 do Johna Cholera z sierpnia 1535, A, t. 11, s. 183 („Vt autem bonae literae seruirent pietati, scripsi Enchiridion militis Christiani; Adagia locupletaui, quod primae aeditionis puderet nimium ieiunae; e Luciano verti dialogos aliquot, ex Euripide tragoedias duas, non ob aliud nisi vt, quoniam deerat praeceptoris copia, ipse memet in Graeco sermone exercerem. Siquidem in hac parte literarum prorsus fui autodidaktos. Praeterae nihil fere scripsi, nisi precibus amicorum adactus: nam ipse malueram alienis legendis animum pascere"). 
Cytowska, M. (1973). Wstęp (s. III-LXVIII). W: Erazm z Rotterdamu. Adagia (wybór). (Przeł. M Cytowska). Wrocław: Zakład Narodowy im. Ossolińskich.

Domański, J. (1973). Erazm i filozofia. Studium o koncepcji filozofii Erazma z Rotterdamu. Wrocław: Zakład Narodowy im. Ossolińskich.

Domański, J. (2005). „Scholastyczne” i „bumanistyczne” pojęcie filozofii. Kęty: Wydawnictwo Antyk.

Garin, E. (Red.). (1951). Prostatori Latini del Quattrocento. Milano-Napoli: Riccardo Ricciardi Editore.

Giese, R. (1934). Erasmus' Greek Studies. The Classical Journal, 29, 517-526.

Hajdukiewicz, L. (1961). Ksiegozbiór i zainteresowania bibliofilskie Piotra Tomickiego na tle jego działalności kulturalnej. Wrocław: Wydawnictwo Polskiej Akademii Nauk.

Hoof, L. V. (2010). Plutarch's practical ethics: The social dynamics of philosophy. New York: Oxford University Press.

Huizinga, J. (1964). Erazm. (Przeł. M. Kurecka). Warszawa: Państwowy Instytut Wydawniczy. Hyma, A. (1930). The youth of Erasmus. Ann Arbor: University of Michigan Press.

Kalita, Z. (1992). Etyka renesansowego bumanizmu. Wykłady z dziejów myśli etycznej. Wrocław: Wydawnictwo Uniwersytetu Wrocławskiego.

Korus, K. (1978). Program wychowawczy Plutarcha z Cheronei. Wrocław: Zakład Narodowy im. Ossolińskich.

Kristeller, P. O. (1970). Erasmus from Italian Perspective. Renaissance Quarterly, 23, 1-14.

Ledeboer, A. M. (1867). Notices bibliographiques des livres imprimés avant 1525 conservés dans la bibliothèque publique de Deventer. Deventer: De Lange.

Mack, P. (2011). A bistory of renaissance rhetoric 1380-1620. New York: Oxford University Press.

Nowicki, A. (Red.). (1966). Filozofia włoskiego odrodzenia. Warszawa: Państwowe Wydawnictwo Naukowe.

Ortiz, A. M. (2000). Plutarco en España: Traducciones de „Moralia” en el siglio XVI. Murcia: Universidad de Murcia.

Overfield, J. H. (1984). Humanism and scholasticism in late medieval Germany. Princeton-New Jersey: Princeton University Press.

Pelc, J. (1984). Europejskość i polskość literatury naszego renesansu. Warszawa: Czytelnik.

Peters, R. (1967). Erasmus and the fathers: Their practical value. Church History, 36, 254-261.

Rummel, E. (1985). Erasmus as a translator of the classics. Toronto-Buffalo-London: University of Toronto Press.

Rummel, E. (1989). Erasmus and the Greek classics (t. 29; s. XXI-XXXIII). W: Erasmus of Rotterdam. Collected works of Erasmus. Toronto-Buffalo-London: University of Toronto Press.

Swieżawski, S. (1974). Dzieje filozofii europejskiej w XV wieku (t. 1). Warszawa: Akademia Teologii Katolickiej.

Szarmach, M. (2001). Plutarch, O słuchaniu. (Przeł. M. Szarmach). Terminus, 2, 87-108.

Woodward, W. H. (1906). Studies in education during the age of Renaissance 1400-1600. Cambridge: Cambridge University Press.

Woodward, W. H. (1964). Desiderius Erasmus concerning the aim and method of education. New York: Columbia University. 
